\title{
A Study on Perception by Examines of the Radiology Department about Exposure to Radioactivity
}

\author{
Jin Dong Yeo*, In ho Ko* \\ Dept. of Radiological Technology, Sorabol College* \\ Dept. of Radiological Technology, Cheju Halla College ${ }^{* *}$

\begin{abstract}
영상의학과 내원 환자의 방사선피폭 인지도에 관한 연구
여진동*, 고인호**

서라벌대학교 방사선과*, 한라대학교 방사선과**
\end{abstract}

\begin{abstract}
The purpose of this study was to investigate factors of perception by inpatients of the radiology department about exposure to radioactivity at the time of radioactive examination, providing basic information for making educational materials aimed to change their perception.

Most of those patients, 65.5\% responded that CT was a type of radioactive examination bringing highest exposure to radiosensitivity. Most of the subjects, $56.1 \%$ said that a body part most vulnerable to exposure to radiosensitivity was the genital gland at the time of radiosensitivity examination. And most of the participants, or $26.3 \%$ responded that they obtained information about radiation from TVs or newspapers.

Among the surveyed patients, men were higher in scores for factors of the perception of radiation such as recognition of radiation, harmfulness of radiation, psychological state at the time of radioactive examination, prevention of exposure to radioactivity and necessity of radiation that women were, with statistically significant differences between the two groups.

These findings suggest that it is urgently needed to develop an education program which helps patients better perceive exposure to radioactivity and that radiologists should be very careful to reduce the does of that exposure. If patients better perceive radiation, they would be less anxious and less exposed to radioactivity when receiving the radioactive examination.
\end{abstract}

Key words : Exposure to Radioactivity, Knowledge, Harmfulness

\section{요 약}

본 연구는 영상의학과 내원 환자를 대상으로 진단용 방사선 검사 시 방사선피폭 인식에 대한 관련요인을 분석하여 방사선피폭 인식의 변화를 위한 교육 자료를 만드는데 기초자료를 제공하기 위해 시도하였다.

방사선 장치 중 가장 방사선 피폭을 가장 많이 받는 검사에 대해서는 전체 $65.5 \%$ 로 CT가 가장 높았으며, 방사선 검사 시 피폭에 가장 민감한 부위에 대해서는 생식선 $56.1 \%$ 가장 많았고, 방사선에 대한 정보 파악은 전체 $26.3 \%$ 가 
TV나 신문을 통해 습득하는 것이 가장 많았다. 방사선 인식도, 방사선 유해성, 방사선 검사 시 심리상태, 방사선 피폭 방지, 방사선 필요성에 대해서는 성 별간 남자가 더 높게 나타났으며, 통계학적으로는 유의한 차이가 있었다.

본 연구를 통해서 환자들로 하여금 방사선피폭에 대하여 올바르게 인식을 할 수 있도록 교육프로그램의 개발이 시 급하며, 방사선사들에게는 환자의 피폭선량을 경감을 위한 세심한 배려가 필요하다고 하겠다. 또한 환자들은 방사선에 대해서 올바르게 인식하는 것이 촬영 시 불안감과 방사선피폭을 줄일 수 있을 것이다.

중심단어: 방사선 피폭, 지식, 유해성

\section{I. 서 론}

\section{1. 연구의 필요성}

현대의학에 있어서 의료용 방사선은 인간의 질병 진단, 치료 및 연구에 활용되어 질병으로부터 인간의 건강을 보호하고 의학을 발전시키는데 중요한 역할을 해왔으며 ${ }^{[1]}$, 근래에는 방사선 의료장비가 인체의 생리 학적, 병리학적 상태를 진단, 치료하는 가장 핵심적인 의료장비로 활용되고 있고 최첨단 방사선 의료 장비 들이 경쟁적으로 개발되고 있어 환자 진료에 그 이용 이 더욱 확대될 전망이다 ${ }^{[2]}$.

방사선이용의 임상적 증가는 방사선종사자 및 환 자들이 방사선에 노출될 기회가 많아질 수 있으멸, 국제방사선 방호위원회에서는 의료방사선 피폭을 환 자 또는 피검자가 의료기관에서 질병의 진료를 위해 방사선에 피폭되는 것으로 정의하고 있으며, 매년 수 천 명의 환자와 방사선작업 종사자들이 방사선에 노 출되고 있다고 보고하고 있다 ${ }^{[4]}$.

의료분야에서 방사선이용은 진단 및 치료에 중대 한 이득을 제공하고 있는 반면 방사선의 피폭으로 장 해요인이 발생되는 것을 부인할 수 없다 ${ }^{[5]}$. 방사선은 양면성을 가지고 있어 적절하게 관리될 때는 유용하 게 사용되지만 관리에 소홀하거나 방심하게 되면 방 사선을 취급하는 사람뿐만 아니라 방사선을 이용하는 환자나 보호자 등에게까지 방사선 피폭에 영향을 주 고 그 정도에 따라 심각한 장해가 발생할 수 있다 ${ }^{[6]}$.

즉 지나친 남용, 관리의 소홀 등으로 상당한 피해를 끼칠 수 있다. 일반인들에게 방사선은 여전히 적절하 게 인식되지 않았으며 방사선 노출에 대해서는 부정 적인 인식이 많다. 이는 임산부 여성에 있어서 $\mathrm{CT}$ 와 같은 검사를 시행하게 되면 기형아에 대한 두려움을
갖게 된다는 것이 대중매체를 통해 발표되었기 때문 이다 ${ }^{[7]}$.

환자의 기준에서 방사선의 피폭은 우리나라 의료 제도 및 의료행위 질병의 복잡성 검사의 의존성 때문 에 증가하는 방사선 검사의 수요에 따라 일반 방사선 피폭선량 준위는 매우 높아져 가고 있는 것이 현실이 다. 의료기관에서 방사선을 이용한 방사선 검사의 연 평균 증가율은 $8.5 \%$ 로 나타나고 있어 환자에 대한 방 사선피폭선량을 최적화하는 중요성은 더욱 크다고 할 수 있다 ${ }^{[8]}$.

한편 환자 측면에서 방사선은 감각이 없고 진단과 정에서 받는 선량으로는 급성 영향 및 장해가 발생될 염려가 없고 침습이 없다. 이와 같은 특성 때문에 방 사선 검사는 쉽게 실시하는 경향이 있어 각 환자마다 적용 판단을 면밀하게 하지 않고 환자들에게 정해진 검사를 획일적으로 실시하는 경향이 있다 ${ }^{[9]}$.

현대 의학에서 방사선 이용의 확대는 필수 불가결 하므로 방사선 이용 및 그 피폭관리에 관한 적절한 대 책수립은 당면 과제로 대두대고 있다 ${ }^{[1]}$. 그러므로 개 인의 방사선피폭뿐만 아니라 전 국민적 차원에서의 피폭선량을 감소시키기 위한 방사선 안전관리 인식 전환이 요구된다 $\left.{ }^{[5]}\right]$. 방사선 이용에 따른 혜택을 최대 화하고, 그 피해를 최소화하기 위해서는 방사선의 적 절한 사용과 관리가 필수 불가결하다 하겠으며 이는 현대 보건의료분야의 주요 부문으로 자리 잡고 있다 [10].

방사선 진단은 인위적 노력에 의해 피폭선량을 감 소시키는 것이 가능한 행위이며, 정부 또는 방사선 관 련단체에서는 환자별 검사 종류와 횟수에 따라 환자 선량을 기록 적산하는 시스템에 적용을 검토하고, 환 자피폭선량을 정기 검사하여 보정해주는 역할을 하여 야 한다고 권고하고 있다 ${ }^{[11]}$. 
따라서 방사선 관련 환자들이 방사선에 노출되는 빈도는 증가하고 있으며, 이와 같은 상황은 계속 증가 할 것으로 기대되기 때문에 방사선 피폭 빈도 또한 지 속적으로 그 이용이 크게 증가 될 전망이다. 방사선이 용의 증가는 환자들이 방사선에 노출될 기회가 많아 질 수 있으며, 이에 따라 방사선이용시 안정성확보가 가장 기본적이고 중요한 요소로 인식되고 있다. 기존 의 선행 논문들을 보면 관계종사자들의 피폭인식과 안전관리에 관한 연구는 이미 많이 이루어져 있다. 그 러나 환자들을 대상으로 한 연구는 충분하지 못한 실 정이다.

따라서 본 연구에서는 방사선에 민감한 반응을 보 이는 영상의학과 내원 환자들을 대상으로 방사선에 인지도를 조사하여 이들의 의식을 먼저 파악하여 분 석함으로써 심리적 불안감을 해소하는데 도움이 되고 자 환자들의 방사선피폭 인지도 관련요인을 조사하여 환자의 피폭방지에 중요성을 인식시키고 기초자료를 제시하고자 본 연구를 시도하였다.

\section{2. 연구의 목적}

본 연구의 목적은 진단용 방사선을 이용하여 검사 를 받는 환자들의 방사선 피폭에 관한 인지도에 영향 을 미치는 요인을 분석하여 파악함으로써 방사선사들 로 하여금 환자의 피폭방지에 대한 중요성을 인식시 키고 기초자료를 제공하고자 함이며 구체적인 목적은 다음과 같다.

첫째, 환자들의 방사선에 대한 인지도를 분석하고 자 한다.

둘째, 방사선 피폭 인식에 관련된 요인을 분석하고 자 한다.

셋째, 방사선 검사 시 내원환자들의 심리상태와 피 폭방지에 대한 인식도를 분석한다.

넷째, 영상의학과 내원 환자들의 방사선에 대한 유 해성 및 정보파악 특성을 분석하고자 한다.

다셋째, 진단용 방사선의 필요성에 대한 인식도를 분석하고자 한다.

\section{II. 연구방법}

\section{1. 연구대상 및 방법}

본 연구의 대상기관인 부산시내 소재하고 있는 2차 의료기관 4개 병원으로서 2013년 6월 1일부터 6월 20 까지 영상의학과에 내원한 환자 중에서 면담이 가능 한 환자 210 명을 대상으로 하였고, 의사표현이 불가능 한 환자를 제외한 환자 중에서 설문조사에 응답할 수 있는 20 세 이상의 환자로 제한하였다. 자료 수집은 설 문지를 통하여 자기기입식으로 이루어졌으며, 조사된 자료 중 응답내용이 불충분하거나 설문에 끝까지 응 답하지 않는 5 명을 제외한 205 명의 설문자료를 본 연 구의 최종 분석에 사용되었다.

\section{2. 연구도구}

이 연구에 사용된 설문지는 영상의학과 내원 환자 들의 방사선 피폭에 대한 인지도에 관련된 요인을 파 악할 수 있도록 문헌 고찰을 통하여 방사선 인지도에 관련된 내용을 도출하고 연구의 목적과 대상자에 맞 게 설문도구를 수정·보완하였다.

설문지 내용은 일반적 특성에 관한 항목 12 문항, 방사선의 인지정도 5 문항, 방사선의 유해성 4 문항, 방 사선 검사 시 심리상태 4문항, 방사선 피폭방지 4문항, 진단용 방사선 필요성 3 문항, 방사선의 지식정도 2 문 항, 방사선 피폭의 정보파악 등의 내용이 포함된 1 문 항 총 34 문항으로 측정하였고, 사용된 전체 문항은 5 점 척도(1)=‘전혀 그렇지 않다' (5)='매우 그렇다')로 구 성하였다.

\section{3. 통계분석}

설문을 통해 수집된 자료는 SPSS(Statistical Package for the Social Sciences) PC Package Program 12.0을 이용 하여 분석하였다.

1) 조사대상자의 일반적 특성에 따른 차이를 분석 파악하기 위해 빈도분석을 실시하였다.

2) 대상자들의 성별에 따라 방사선에 대한 인식도, 방사선의 유해성, 방사선 검사 시 심리적 상태, 방사선 의 피폭방지 인식, 진단용 방사선의 필요성, 방사선의 지식정도, 방사선의 피폭 정보파악 정도의 차이는 t-test로 분석을 실시하였다. 
3) 각 요인 간 상관관계를 알아보기 위하여 상관분 석을 실시하였다.

4) 방사선 인지도, 유해성 인지도, 방사선 검사 시 심리상대, 방사선 피폭방지, 진단용 방사선의 필요성 인지도간의 관련성을 알아보기 위해 다중회귀분석을 실시하였다.

\section{III. 연구결과}

\section{1. 연구대상자의 일반적 특성}

연구대상자의 일반적 특성은 다음 (Table 1)과 같다. 연령별로는 30 대가 $50.2 \%$ 로 가장 많았으며, 다음으로 는 20 대 $23.4 \%, 40$ 대 $19.5 \%$ 의 순으로 나타났다.

학력은 고졸 $61.0 \%$ 로 가장 많았고, 다음은 전문대 졸 $36.1 \%$ 순으로 나타났으며, 종교는 없다는 응답이 $57.1 \%$ 로 가장 많았다. 월평균 수입은 300 만원 이하가 $43.4 \%$ 로 가장 많았고, 다음으로는 300 만원-399만원 $25.9 \%, 500$ 만원 이상 $18.0 \%$ 의 순으로 나타났다.

진료구분은 외래가 전체 $83.9 \%$ 로 대부분 차지했고, 방사선 검사횟수는 3-6번 $33.7 \%, 10$ 번 이상 $33.7 \%$ 로 가 장 많았으며, 다음으로는 1-2번 18.0\%, 7-9번 14.6\%등의 순으로 나타났다.

방사선 검사 종류는 일반촬영 $57.6 \%$ 로 가장 많았 고, 초음파 $13.7 \%$, CT촬영 $12.7 \%$ 등의 순으로 나타났 다(Table 1).

\section{2. 방사선의 지식정도 및 정보파악}

방사선 장치 중 가장 방사선 피폭을 가장 많이 받
는 검사에 대해서는 CT가 $65.4 \%$ 로 가장 높았으며, 일 반촬영 및 특수촬영 $21.9 \%$, MRI 및 초음파가 $12.7 \%$ 순 으로 인식하고 있는 것으로 나타났고, 방사선 검사 시 피폭에 가장 민감한 부위에 대해서는 생식선 $56.1 \%$ 가 장 많았으며, 갑상선 $25.4 \%$, 뇌 $11.7 \%$ 순으로 나타났다.

방사선에 대한 정보는 전체 $26.3 \%$ 가 TV나 신문을 통하여 인식하는 것이 가장 많았으며, 다음은 인터넷 $25.4 \%$, 병원직원 $24.4 \%$, 주위사람 $12.7 \%$ 로 나타났다 (Table 2).

\section{3. 방사선 인지도에 대한 신뢰도 검증}

본 연구에서는 신뢰성을 검정하기 위하여 구성요 소별로 Cronbach's alpha 계수를 이용하였다. Cronbach's alpha 계수의 경우는 신뢰성 분석의 개념인 내적 일관 성에 대한 것으로 하나의 개념에 대하여 여러 개의 항 목으로 구성되는 척도에 이용하는 방법으로 해당문항 들로 할 수 모든 가능한 반분 신뢰도를 구하고 이의 평균치를 산출한 것이 alpha 계수 값이 되는데, 일반적 으로 0.6 이상이 되어 본 설문도구를 이용하여 설문조 사를 실시하게 되었다.

방사선 인지도에 미치는 요인을 구성하는 6 개 문 항의 Cronbach's alpha 계수는 .866로 나타났고, 방사선 유해성 미치는 요인은 3 개 문항의 Cronbach's alpha 계 수는 .782, 방사선 검사 시 심리상태 요인은 5 개 문항 의 Cronbach's alpha 계수는 .654, 방사선 피폭방지 요인 은 4개 문항의 Cronbach's alpha 계수는 .786로 내적 일 치도를 보였다. 그리고 방사선사 직업의식은 6 개 문항 은 Cronbach's alpha 계수는 .828로 높은 내적 일치 도 를 보였다(Table 3).

Table 1. Demographic Characteristics of the Subjects

unit : number(\%)

\begin{tabular}{|c|c|c|c|}
\hline Item & Classification & Frequency & $\%$ \\
\hline \multirow{2}{*}{ Gender } & Male & 78 & 38.0 \\
\hline & Female & 127 & 62.0 \\
\hline \multirow{2}{*}{ Marital Status } & Married & 47 & 22.9 \\
\hline & Single & 158 & 77.1 \\
\hline \multirow{4}{*}{ Age } & $20 \mathrm{~s}$ & 48 & 23.4 \\
\hline & $30 \mathrm{~s}$ & 103 & 50.2 \\
\hline & $40 \mathrm{~s}$ & 40 & 19.5 \\
\hline & 50 s or older & 14 & 6.8 \\
\hline
\end{tabular}


"Journal of the Korean Society of Radiology, Volume 7, Number 5"

\begin{tabular}{|c|c|c|c|}
\hline \multirow{3}{*}{ Educat ion } & High school graduate & 125 & 61.0 \\
\hline & Junior col lege graduate & 74 & 36.1 \\
\hline & College graduate or higher & 6 & 2.9 \\
\hline \multirow{2}{*}{ Religion } & Yes & 88 & 42.9 \\
\hline & № & 117 & 57.1 \\
\hline \multirow{4}{*}{ Occupation } & Self-employed person & 15 & 7.3 \\
\hline & Salar ied person & 50 & 24.4 \\
\hline & Professional & 24 & 11.7 \\
\hline & Others(student, housewi fe) & 116 & 56.6 \\
\hline \multirow{4}{*}{ Monthly household income } & 3 million Won or below & 89 & 43.4 \\
\hline & $3-3.99$ mill ion Won & 53 & 25.9 \\
\hline & $4-4.99$ mill ion Won & 26 & 12.7 \\
\hline & 5 million or over & 37 & 18.0 \\
\hline \multirow{2}{*}{ Type of Patient } & Inpatient & 33 & 16.1 \\
\hline & Outpat ient & 172 & 83.9 \\
\hline \multirow{4}{*}{ Depar tment } & Internal medicine & 36 & 17.6 \\
\hline & Surgery & 55 & 26.8 \\
\hline & Pediatr ics(gynecology) & 24 & 11.7 \\
\hline & $\begin{array}{l}\text { Others(emergency room, heal th } \\
\text { examination) }\end{array}$ & 90 & 43.9 \\
\hline \multirow{4}{*}{$\begin{array}{l}\text { Frequency of the } \\
\text { radioact ive examination }\end{array}$} & $1-2$ & 37 & 18.0 \\
\hline & $3-6$ & 69 & 33.7 \\
\hline & $7-9$ & 30 & 14.6 \\
\hline & 10 or more & 69 & 33.7 \\
\hline \multirow{5}{*}{$\begin{array}{l}\text { Type of the radioact ivity } \\
\text { check }\end{array}$} & General photography & 118 & 57.6 \\
\hline & Special photography & 20 & 9.8 \\
\hline & $\mathrm{CT}$ & 26 & 12.7 \\
\hline & MRI & 13 & 6.3 \\
\hline & Ul trasonography & 28 & 13.7 \\
\hline & Total & 205 & 100.0 \\
\hline
\end{tabular}

Table 2. Knowledge and Information of Radiation

unit : number(\%)

\begin{tabular}{llcc}
\hline \multicolumn{1}{c}{ Item } & \multicolumn{1}{c}{ Classification } & Frequency & $\%$ \\
\hline \hline $\begin{array}{l}\text { Examinations that bring highest General photography, } \\
\text { exposure }\end{array}$ & special & 45 & 21.9 \\
to radioact ivity & CT & 134 & 65.4 \\
& MRI, ul trasonography & 26 & 12.7 \\
\hline Body parts most vulnerable & Brain & 24 & 11.7 \\
to exposure to radioactivity & Ear & 6 & 2.9 \\
& Hairs & 8 & 3.9 \\
& Thyroid gland & 52 & 25.4 \\
& Genital gland & 115 & 56.1 \\
\hline Source of information about & Hospital staff & 50 & 24.4 \\
radiation & TV • newspapers & 54 & 26.3 \\
& Internet & 52 & 25.4 \\
& Acquaintance & 26 & 12.7 \\
& Others & 23 & 11.2 \\
\hline
\end{tabular}


Table 3. Reliability Test Results for Question Items of this Study

\begin{tabular}{lll}
\hline Variable & No. of Items & Cronbach's alpha Coefficient \\
\hline \hline Preception of radiation & 6 & .866 \\
Harmfulness of radiation & 3 & .782 \\
Psychological state at the time of & 5 & .654 \\
radioact ive examination & 4 & .786 \\
Prevention of exposure to radioactivity & 3 & .761 \\
Necessity of radiation & 6 & .828 \\
Professional consciousness as the & & \\
radiologist & 27 & \\
\hline Total &
\end{tabular}

\section{4. 방사선피폭 인지도}

방사선 인식도에 미치는 영향은 '진단용 방사선에 대해 알고 있다고 생각 하는가'에 대해서는 남자는 평 균 $3.83 \pm 1.200$, 여자는 $3.01 \pm 1.165$ 로 나타났고, '진단용 방사선은 반드시 필요하다고 생각 하는가'에 대해서 남자는 평균 $4.42 \pm .892$, 여자는 $3.51 \pm 1.214$, '방사선 검 사를 하게 되면 방사선 피폭을 받는다고 생각 하는가'

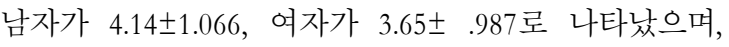
'일상생활 중에도 방사선에 노출되었다고 생각 하는 가'에 대해서 남자는 $3.73 \pm 1.266$, 여자는 $3.19 \pm 1.239$ 로 나타나 성 별간 남자가 더 높게 나타났으며, 통계학적 으로는 유의한 차이가 있었다.

방사선유해성에 대해서는 '핵의학과나 종양학과에 서 사용되는 방사선은 진단용 방사선보다 유해하다고 생각 하는가'에 대해서 남자가 $3.96 \pm 1.156$, 여자가 $3.19 \pm .982$ 로 성 별간 남자가 더 높게 나타났으며, '진 단용 방사선의 안전성에서 사람의 유전적 신체적으로 영향을 미치고 있다고 생각 하는가'는 남자는 $3.26 \pm 1.180$, 여자는 $3.53 \pm 1.056$ 로 나타나 성 별간 여자 가 더 높게 나타났으며, 통계학적으로는 유의한 차이 가 있었다.

방사선 검사 시 심리상태에 대해서는 방사선 검사 시 방사선피폭이 두렵거나 걱정이 된다고 생각 하는

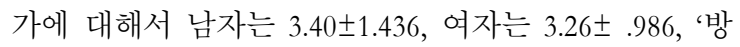
사선 검사 후 피폭으로 인해 몸이 이상이 생길까 걱정 하셨던 적이 있는가'에 대해서는 남자가 $3.22 \pm 1.429$, 여 자가 $3.17 \pm 1.006$ 로 나타나 성 별 간 남자가 높게 나타 났으며, 성 별간 통계학적으로 유의한 차이가 없었다. '방사선 검사 시 방사선사가 방사선 피폭에 대해 설명
을 잘 해준다고 생각 하는가 남자는 $2.82 \pm 1.078$, 여자 는 $2.59 \pm .894$ 로 나타나 성 별간 남자가 더 높게 나타났 으며, 통계학적으로는 유의한 차이가 있었다.

방사선 피폭방지에 대해서는 '방사선사가 환자나 보호자에게 불필요한 방사선 피폭을 줄이기 위해 노 력을 하고 있다고 생각 하는가'에 대해서는 남자가 $3.81 \pm 1.070$, 여자가 $2.87 \pm .984$, 방사선 방어 복을 착용 하면 방사선 피폭을 줄일 수 있다고 생각 하는가'는 남자가 $3.97 \pm .868$, 여자가 $3.57 \pm .822$, 방사선 검사 시 문을 닫고 검사하면 문밖에서 방사선 피폭을 줄일 수

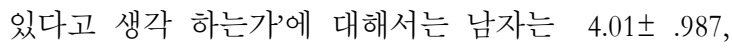

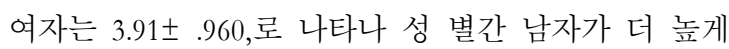
나타났으며, 통계학적으로는 유의한 차이가 있었다.

방사선 필요성에 대해서는 '질병을 진단하기 위해 방사선 검사가 꼭 필요하다고 생각 하는가, 남자는 $4.50 \pm .640$, 여자는 $3.87 \pm 1.023$, '방사선 검사 시 받게 되 는 방사선 피폭에 비해 질병의 진단으로 얻게 되는 이 익이 더 많다고 생각 하는가, 남자가 $4.42 \pm .765$, 여자 가 $3.73 \pm 1.185$, '진단을 위하여 추가로 다른 진단용 방 사선 검사를 받기 원 하는가'에 대해서는 남자는 $3.82 \pm 1.125$, 여자는 $3.57 \pm .859$ 로 성 별간 남자가 더 높 게 나타났으며, 통계학적으로는 유의한 차이가 있었다 (Table 4).

\section{5. 방사선사 직업의식}

방사선사 직업의식에 대해서는 '방사선사 직업은 앞으로 계속 발전할 것이다'에 대해서는 남자는

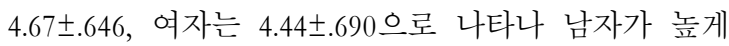
나타났으며, 통계학적으로는 유의한 차이는 없었다. 
"Journal of the Korean Society of Radiology, Volume 7, Number 5"

'방사선사 직업은 많은 사람들이 선호하는 직업이다' 에 대해서는 남자가 $3.38 \pm 1.140$, 여자가 $4.06 \pm .785$ 로 나 타나 여자가 높게 나타나 통계학적으로 유의한 차이 가 있었다. '방사선사는 안정적인 직장이다'에 대해서

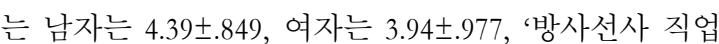
은 사회적으로 많은 인정을 받고 있다'에 대해서는 남 자가 $3.90 \pm 1.199$, 여자가 $3.72 \pm .876$ 로 나타나 성별 간 남자가 더 높게 나타났으며, 통계학적으로 유의한 차 이가 있었다(Table 5).

\section{6. 방사선피폭 인지도 요인의 상관관계}

다음은 방사선피폭 인지도 요인의 상관관계를 분 석한 결과이다. 다음은 방사선피폭 인지도 요인의 상 관관계를 보면, 인식도, 유해성 심리상태, 피폭방지 요 인은 상관관계를 가지는 것으로 나타났고, 인식도에 따른 상관관계를 보면 유해성 심리상태, 피폭방지, 방
사선필요성 요인은 통계학적으로 유의한 상관관계를 보인다(Table 6).

\section{7. 방사선피폭 인지도에 영향을 미치는 요인별 대 한 회귀 분석}

방사선피폭 인지도에 영향을 미치는 요인별 회귀 분석을 위하여 유해성, 심리상태, 피폭방지, 방사선필 요성을 독립변수로 하고 인식도를 종속변수로 하여 다중회귀분석을 실시한 결과는 (Table 7)과 같다. 분석 결과 $\mathrm{F}$ 분포를 통해 고려할 때 이 회귀방정식의 유의도 수준은 모두 유의한 것으로 나타났고, $\mathrm{R}^{2}$ 값은 $83 \%$ 로 조사되었다.

방사선피폭 인지도에 영향을 미치는 요인 중에서 유해성, 심리상태, 피폭방지, 방사선필요성은 유의한 양(+)의 영향을 미치는 것으로 나타났다.

Table 4. Gender-specific perception on the radiation

Unit : $\mathrm{M} \pm \mathrm{SD}$

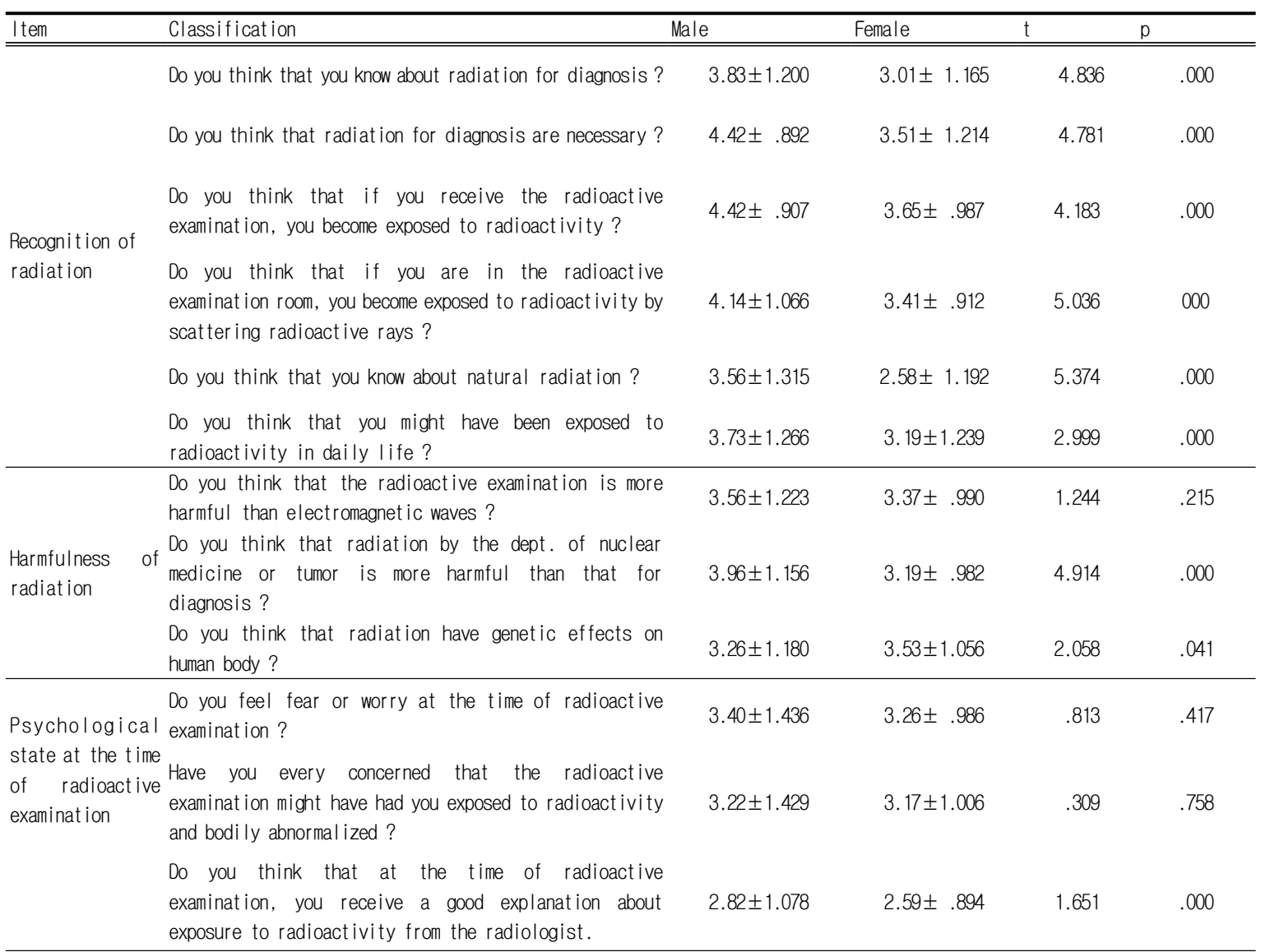


"A Study on Perception by Examines of the Radiology Department about Exposure to Radioactivity "

\begin{tabular}{|c|c|c|c|c|c|}
\hline & $\begin{array}{l}\text { Do you think that it feels bad not to be given any } \\
\text { explanation about exposure to radioactivity at the time } \\
\text { of radioactive examination? }\end{array}$ & $3.18 \pm 1.277$ & $3.28 \pm .940$ & -.618 & .537 \\
\hline \multirow{4}{*}{$\begin{array}{l}\text { Prevention of } \\
\text { exposure to } \\
\text { radioact ivity }\end{array}$} & Do you know how to reduce exposure to radioactivity? & $3.55 \pm 1.355$ & $2.44 \pm 1.251$ & 5.864 & .000 \\
\hline & $\begin{array}{l}\text { Do you think that the radiologist tries to reduce } \\
\text { unnecessary exposure of the patient or his/her } \\
\text { caregivers to radioactivity? }\end{array}$ & $3.81 \pm 1.070$ & $2.87 \pm .984$ & 6.253 & .000 \\
\hline & $\begin{array}{l}\text { Do you think that wear ing ant i-radioact ivity clothes can } \\
\text { reduce irradiation? }\end{array}$ & $3.97 \pm .868$ & $3.57 \pm .822$ & 3.330 & .001 \\
\hline & $\begin{array}{l}\text { Do you think that if the door of the radioactive } \\
\text { examination room is closed, people outside the room can } \\
\text { be kept from being exposed to radioactivity? }\end{array}$ & $4.01 \pm .987$ & $3.91 \pm .960$ & 4.447 & .000 \\
\hline \multirow{3}{*}{$\begin{array}{l}\text { Necessity of } \\
\text { radiation }\end{array}$} & $\begin{array}{l}\text { Do you think that the radioactive examination is } \\
\text { necessary to diagnose disease? }\end{array}$ & $4.50 \pm .640$ & $3.87 \pm 1.023$ & 5.389 & .000 \\
\hline & $\begin{array}{l}\text { Do you think that diagnosis by the radioactive } \\
\text { examination is so beneficial enough to set of } f \text { exposure } \\
\text { to radioactivity from that check? }\end{array}$ & $4.42 \pm .765$ & $3.73 \pm 1.185$ & 5.071 & .000 \\
\hline & $\begin{array}{l}\text { Do you want to receive another type of radioactive } \\
\text { examination for diagnosis? }\end{array}$ & $3.82 \pm 1.125$ & $3.57 \pm .859$ & 1.655 & .000 \\
\hline
\end{tabular}

Table 5. Professional Consciousness as the Radiologist

\begin{tabular}{lcccc}
\hline Classification & Male & Female & $\mathrm{t}$ & $\mathrm{p}$ \\
\hline \hline This profession will go on developing. & $4.67 \pm .646$ & $4.44 \pm .690$ & 2.471 & .087 \\
This profession is prefer red by lots of people. & $3.38 \pm 1.140$ & $4.06 \pm .785$ & 37.204 & .000 \\
I has the true consciousness of duty as a radiologist. & $4.10 \pm .873$ & $3.89 \pm .881$ & 18.974 & .000 \\
This profession is a stable job. & $4.39 \pm .849$ & $3.94 \pm .977$ & 5.941 & .003 \\
This profession has a high social reputation & $4.10 \pm 1.025$ & $3.94 \pm .785$ & 9.788 & .000 \\
This profession is socially much recognized. & $3.90 \pm 1.199$ & $3.72 \pm .876$ & 7.777 & .001 \\
\hline
\end{tabular}

Table 6. Correlations among Factors of the Perception of Exposure to Radioactivity

\begin{tabular}{|c|c|c|c|c|}
\hline Classification & Degree of Recognition & Harmfulness & Psychological State & $\begin{array}{c}\text { Prevention of exposure } \\
\text { to radioactivity }\end{array}$ \\
\hline Harmfulness & 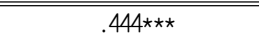 & & & \\
\hline Psychological state & $.501 \star \star$ & $.302 \star \star$ & & \\
\hline $\begin{array}{l}\text { Prevention of exposure } \\
\text { to radioactivity }\end{array}$ & 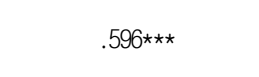 & $.362 \star \star \star *$ & $.240 * \star$ & \\
\hline Necessity of radiation & 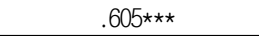 & .254 *** & 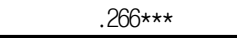 & $.541 \star \star \star$ \\
\hline
\end{tabular}

$* * * \mathrm{p}<0.001, * * \mathrm{p}<0.01$ 
"Journal of the Korean Society of Radiology, Volume 7, Number 5"

Table 7. Regression Analysis on Factors Affecting the Perception of Exposure to Radioactivity

\begin{tabular}{|c|c|c|c|c|}
\hline Variable & $\mathrm{B}$ & Beta & $\mathrm{t}$ & $p$ \\
\hline Harmfulness & .450 & +.228 & 4.501 & .000 \\
\hline Psychological state & .190 & .108 & 2.079 & .039 \\
\hline Prevention of exposure to radioactivity & .692 & .439 & 6.620 & .000 \\
\hline Necessity of radiation & .749 & .341 & 6.620 & .000 \\
\hline Gendera & -1.652 & -.147 & -2.869 & .000 \\
\hline Marital statusb & .402 & .031 & .612 & .541 \\
\hline Religionc & -1.333 & .563 & -2.367 & .019 \\
\hline $30 \mathrm{sd}$ & -1.333 & -.251 & -3.505 & .001 \\
\hline 40sd & -4.187 & -.305 & -4.243 & .000 \\
\hline $50 \mathrm{sd}$ & -1.874 & -.087 & -1.465 & .145 \\
\hline Junior college graduatee & 1.834 & .164 & 1.136 & .258 \\
\hline College graduate or highere & .477 & .042 & .282 & .778 \\
\hline $3-3.99 \mathrm{mi}$ Il ion Wonf & .352 & .028 & .573 & .567 \\
\hline $4-4.99$ million Wonf & -4.141 & -.253 & -5.113 & .000 \\
\hline 5 million Won or over $f$ & -1.048 & -.074 & -1.365 & .174 \\
\hline Salar ied persong & -.921 & -.073 & -.854 & .394 \\
\hline Special istg & -3.229 & -.191 & -2.704 & .008 \\
\hline Othersg & -2.258 & -.205 & -2.280 & .024 \\
\hline Type of patienth & 2.215 & .149 & 2.728 & .007 \\
\hline Exper ience of the radioactive examinationi & -1.784 & -.109 & -2.048 & .042 \\
\hline Intercept & -.719 & & -.2645 & .792 \\
\hline F-value & & & & 21.100 \\
\hline$p$ & & & & .000 \\
\hline$R^{2}$ (Adjust-R2) & & & & $.834(.696)$ \\
\hline
\end{tabular}

independent variable : degree of recognition

reference groups : $\mathrm{a}=$ male, $\mathrm{b}=$ single, $\mathrm{c}=$ yes, $\mathrm{d}=20 \mathrm{~s}, \mathrm{e}=$ high school graduate, $\mathrm{f}=$ below

300million Won, $\mathrm{g}=$ self-employed person, $\mathrm{h}=$ inpatient, $\mathrm{i}=$ yes

\section{IV. 고 찰}

최근 의료기술의 발달과 더불어 방사선 관련 시술 이 복잡하고 광범위해지면서 환자들이 방사선피폭에 노출될 기회가 많아지고 있다 ${ }^{[12][13]}$. 현대의학에 있어 서 의료용 방사선 이용은 인간의 질병 치료와 예방 및 연구에 활용되어 질병으로부터 생명을 보호하고 의학 을 발전시키는데 막중한 역할을 해왔다.

다른 한편으로 환자들이 방사선 검사에 노출되는 기회가 날로 증가하고 있으며, 이와 같은 이용은 앞으 로 증가될 것으로 기대되기 때문에 방사선 피폭 기회 또한 계속 증가할 것으로 전망된다. 그러므로 방사선 종사자 및 환자나 보호자의 피폭을 개선하지 않으면 전 국민의 잠재적인 방사선피해가 축적되어 후손에게 좋지 않은 결과를 초래할 수도 있다.
방사선 장치 중 가장 방사선 피폭을 가장 많이 받는 검사에 대해서는 CT가 $65.4 \%$ 로 가장 높았으며, 일반촬영 및 특수촬영 $21.9 \%$, MRI 및 초음파가 $12.7 \%$ 순으로 분석되어 CT가 가장 유해하다고 인식하고 있 는 것으로 나타났는데, 이는 박 ${ }^{[10]}$, 이 ${ }^{[14]}$ 의 결과와 일 치하였고, 이러한 결과는 대중매체에서도 CT검사로 인한 발암 가능성에 대하여 보도가 되고 있기 때문인 것으로 생각된다.

방사선 검사 시 피폭에 가장 민감한 부위에 대해 서는 생식선이 $56.1 \%$ 로 가장 높게 나타났는데, 이는 생식선은 인체조직중 방사선에 의해 손상받기 쉬운 장기이고 나이가 어릴수록 방사선에 민감하다는 점을 감안할 때 소아의 방사선 검사와 치료 시는 더욱 신중 을 기해야 할 것으로 사료된다.

방사선에 대한 정보는 전체 $26.3 \%$ 가 TV나 신문을 
통하여 습득하는 것이 가장 많았으며, 다음은 인터넷 $25.4 \%$, 병원직원 $24.4 \%$, 주위사람 $12.7 \%$ 로 나타났다. 이는 박 ${ }^{[10]}$, 여, 김 ${ }^{[15]}$ 의 결과와 일치하였고, 이는 의료 행위와 관련된 방사선피폭은 진단을 정확하게 하는데 도움이 되는 정보를 우선으로 하고 있어 피폭과 관련 된 문제들은 등한시하게 되는 경향이 있으나 피폭감 소도 진단 정보 못지않게 중요하다.

방사선 인식도에 미치는 영향은 '진단용 방사선은 반드시 필요하다고 생각 하는가'에 대해서 남자는 평

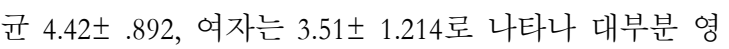
상의학과 내원환자들은 진단용 방사선의 필요성을 인 식하고 있는 것으로 나타났다. '자연방사선에 대해 알 고 있다고 생각 하는가' 남자 $3.56 \pm 1.315$, 여자 $2.58 \pm$ 1.192 로 나타나 이 결과는 박 ${ }^{[10]}$ 의 연구보다 조금 높은 인지도를 보였고, 이는 대부분 환자들이 자연방사선에 대해서는 인식도가 부족한 것으로 나타났다.

방사선유해성에 대해서는 진단용 방사선의 안전성 에서 사람의 유전적 신체적으로 영향을 미치고 있다 고 생각 하는가는 남자는 $3.26 \pm 1.180$, 여자는 $3.53 \pm 1.056$ 로 성별 간 여자가 더 높게 나타났는데, 이 는 본 연구에서 산부인과 진료환자들이 방사선에 민 감한 여성들을 대상으로 한 결과라고 생각할 수 있으 며, 방사선 검사 시 환자 자신에 대한 피폭보다는 태 아에 대한 관심이 많은 것으로 나타났다. 이는 미량의 방사선 피폭이라도 장기적으로 여러 번 노출되면 유 전적인 영향이나 백혈병 등의 발생확률이 높아지므로 방사선사는 방사선 피폭의 최저준위가 되는 업무를 수행하지 않으면 안 되며, 국제방사선방호위원회( International Commission on Radiological Protection)에서 권장하는 허용선량을 초과하지 않도록 만전을 기울여 야 할 것이다 ${ }^{[14]}$.

방사선 검사 시 심리상태에 대해서는 방사선 검사 시 방사선사가 방사선 피폭에 대해 설명을 잘 해준다

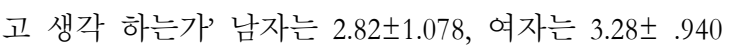
로 낮게 나타났으며, 방사선사는 충분한 설명이 필요 한 것으로 나타났다.

방사선 피폭방지에 대해서는 방사선사가 환자나 보호자에게 불필요한 방사선 피폭을 줄이기 위해 노 력을 하고 있다고 생각 하는가에 대해서는 남자가
$3.81 \pm 1.070$, 여자가 $2.87 \pm .984$ 로 나타나 방사선사는 방 사선 검사 시 안전관리에 더욱 세심하고 불필요한 오 해의 소지를 사전에 방지하기 위한 교육과 노력이 필 요하다 할 수 있다.

방사선 필요성에 대해서는 '질병을 진단하기 위해 방사선 검사가 꼭 필요하다고 생각 하는가' 남자는 $4.50 \pm .640$, 여자는 $3.87 \pm 1.023$, '진단을 위하여 추가로 다른 진단용 방사선 검사를 받기 원 하는가'에 대해서 는 남자는 $3.82 \pm 1.125$, 여자는 $3.57 \pm .859$ 로 나타나 방 사선 검사 경험이 있는 경우가 진단용 방사선에 대한 관심이 더 높기 때문일 것으로 생각된다.

방사선사 직업의식에 대해서는 '방사선사 직업은 앞으로 계속 발전할 것이다' '사회적으로 좋은 명성을 갖고 있다 직업의식에 대해서는 성 별간 남자가 더 높게 나타났으며, 통계학적으로 유의한 차이가 있었 고, 즉 방사선사는 국민건강 향상에 중요한 역할을 하 고, 사명감이나 소명의식이 있으며 직업은 사회적으로 좋은 명성을 갖고 있고 긍정적으로 나타났다.

방사선피폭 인지도에 영향을 미치는 요인별 회귀 분석을 위하여 방사선유해성, 방사선 심리상태, 방사 선 피폭방지, 방사선필요성을 독립변수로 하고 인식도 를 종속변수로 하여 다중회귀분석을 실시한 분석결과 $\mathrm{F}$ 분포를 통해 고려할 때 이 회귀방정식의 유의도 수준 은 모두 유의한 것으로 나타났고, $\mathrm{R}^{2}$ 값은 $83 \%$ 로 조사 되었다. 방사선피폭 인지도에 영향을 미치는 요인 중 에서 방사선유해성, 방사선 심리상태, 방사선피폭방지, 방사선필요성은 유의한 영향을 미치는 것으로 나타났 다.

진단 방사선 검사 중 환자가 받는 선량은 인위적 으로 만들어낸 방사선 피폭 중 가장 큰 비중을 차지하 고 있으며, 국제적으로 방사선 피폭에 대한 진단 참고 준위가 제안되고 있으며, 본 연구의 대상기관인 부산 시내 소재하고 있는 2 차 의료기관 4 개 병원으로서 2013년 6월 1일부터 6월 20까지 영상의학과에 내원한 환자 중에서 면담이 가능한 환자 210 명을 대상으로 하 였고, 국제원자력기구(International Atomic Energy Agency)는 진단방사선 검사와 방사선 동위원소 검사를 위한 유도준위(guidance level)를 정하여 각국의 실정에 맞게 사용하도록 권고하고 있다. 따라서 다수의 나라 
에서는 자국의 실정에 맞는 진단참고 준위를 정하고 자 진단방사선검사에서 환자피폭에 관한 상황을 조사 분석하고 있다. 또한 한국의 실정에 맞는 진단방사선 검사에서의 진단 참고 준위가 제시 되고 있다.

방사선에 대한 지식을 높이기 위해서는 지속적인 방사선의 위해성에 대한 올바른 교육을 통해 이해를 높여야 한다. 이를 통해 불필요한 방사선피폭을 줄여 환자 및 보호자는 물론 종사자에게 건강상의 불이익 을 미연에 방지하는 계기를 마련해야 할 것이다. 향후 환자뿐만 아니라 방사선종사자 및 국민의 피폭선량이 경감되어 건강한 삶을 영위하기 위해서는 향후 방사 선피폭과 관련하여 보다 다양한 요인들에 대한 연구 가 필요하리라 사료된다.

\section{$\mathrm{V}$. 결 론}

본 연구는 영상의학과 내원 환자를 대상으로 진단 용 방사선 검사 시 방사선피폭 인식에 대한 관련요인 을 분석하여 방사선피폭 인식의 변화를 위한 교육 자 료를 만드는데 기초자료를 제공하기 위해 시도하였다.

2013년 6월 1일부터 6월 20일에 걸쳐 부산시내 소 재하고 있는 2 차 의료기관 4 개 병원 영상의학과에 내 원한 환자 210 을 조사대상으로 하였으며, 자료 수집은 구조화된 설문지를 통하여 이루어졌다. 이에 결과를 요약하면 다음과 같다.

본 연구를 통해서 환자들로 하여금 방사선피폭에 대하여 올바르게 인식을 할 수 있도록 교육프로그램 의 개발이 시급하며, 방사선사들에게는 환자의 피폭선 량을 경감을 위한 세심한 배려가 필요하다고 하겠다. 또한 환자들은 방사선에 대해서 올바르게 인식하는 것이 촬영 시 불안감과 방사선피폭을 줄일 수 있을 것 이다.

\section{참고문헌}

[1] Hyun Chul Cho, Study on perception and behavior about radiation safety management and Measurement of radiation dose for workers who work in the angiography room, Graduate School of Public Health Korea University, pp.1-9, 2004.

[2] Akio Sato, About the outline about the radiation pamphlet for the citizen, 4th The International Joint Conference of KTJ Radiological Technologists, pp.88, 2001.
[3] Hyun Soo Kim, Study on the knowledge, Perceptyion, and Behavior about the Protection of Workers Who have Risk of Radiation Eposure in Hospital, Graduate School of Health Science and Management, pp.5-23, 2000.

[4] UNSCERA, Source and Effects of Ionizing Radiation, United nayions, New York., 2000.

[5] Jai Dong Rhim, A Comparative Analysis of Personnel Awareness for the Safety Management Rule in Diagnosis Purpose Radiation, Gradute School of Administrative Science Yonsei University, pp.1-19, 2000

[6] Nak Sang Kim, The Survey of Radiologic technologist's sense engaged in Dept. of diganostic radiology about radiation protection, Gradute School of Public Health Kyungsan National University, pp.1-8, 2000

[7] Akio Sato, About the outline about the radiation pamphlet for the citizen, 4th The International Joint Conference of KTJ Radiological Technologists, p88, 2006.

[8] Jeong kyu Park, A Study on Gynecologic Patients Recognition about Radiation Exposure, Graduate School of Health Promotion Hanseo University, pp.1-42, 2001.

[9] Jun Heo, Radiation Protection for the Patient, Journal of Radiological Science and Technoligy, VoI. 20, No. 2, pp.14-18, 1997.

[10] Jeong Kyu Park, A Study on Gynecologic Patients Recognition about Radiation Exposure, Graduate School of Health Promotion Hanseo University. pp.1-38, 2008.

[11] Yoo Hyun Kim, Patient Exposure Dose from Medical X-ray Examination in Korea, Radiological Technology, VoI. 41, No. 1, pp.241-248, 2005.

[12] J.D. Yeo, H.S. Kim, A study on the image of radiologists perceived by college students of radiology, The Korean Journal of Health Service Management, Vol. 7 No. 1, pp.107-118, 2013.

[13] Eun Ok Han, Byung Sub Park), Knowledges, consciousnesses, and attitudes of some university students on the use of radiation, The Korean Journal of Health Service Management, Vol. 30, No. 4, pp.221-230, 2005

[14] Hwan Hyung Lee, Management on Radiation Exposure of Radiological Technologist Working in Medical Facilitis, Gradute School of Public Health Kyungpook National University, pp.1-6, 1991.

[15] J.K. Yeo, H.S. Kim, Relations between radiologists' job stress and intent of separation, The Korean Journal of Health Service Management, Vol.5, No. 2, pp.35-51, 2000. 